Tohoku J. exp. Med., 1977, 121, 85-90

\title{
Immunohistochemical Demonstration of Somatostatin-Positive Cells in the Canine Gut
}

\author{
Setki Ito, Yukio Yamada and Shigeru Kobayashi* \\ The First Department of Internal Medicine and *the Department \\ of Anatomy, Nïgata University School of Medicine, Nirgata
}

\begin{abstract}
Ito, S., Yalrada, Y. and Kobayashi, S. Immunohistochemical Demonstration of Somatostatim-Positive Cells in the Canine Gut. Tohoku J. exp. Med., 1977, 121 (1), 85-90 _ Somatostatin-immunoreactive cells in the canine gut were investigated by an indirect immunofluorescent technique. Somatostatin-positive cells were demonstrated in the neck portion of the pyloric gland and in the bottom of the intestinal crypt, and these cells were distinguished from those in other organs by the presence of a cytoplasmic process reaching the gut lumen (external environment). Possible functional meaning of this cytoplasmic process was discussed. —_ somatostatin; canine gut; immunofuorescence
\end{abstract}

Somatostatin, a peptide originally isolated from the sheep hypothalamus, has an ability to suppress the secretion of pituitary hormones, somatotropin and thyrotropin (Brazeau et al. 1973). It has also extra-pituitary properties such as inhibitory action on the secretion of insulin and glucagon from the pancreatic islet (Alberti et al. 1973; Gerich et al. 1974) and of hydrochloric acid and pepsin from the fundic gland (Bloom et al. 1974; Barros D'Sa et al. 1975; Gomez-Pan et al. 1975).

Cellular localization of somatostatin has been studied by the immunofluorescence technique using anti-somatostatin antisera. Cells reacting with antisomatostatin antisera (somatostatin-positive cells) were demonstrated not only in the hypothalamus (Hökfelt et al. 1975) but also in some of the extra-hypothalamic tissues such as posterior pituitary (Hökfelt et al. 1975), thyroid gland (Hökfelt et al. 1975) and pancreatic islet (Luft et al. 1974; Polak et al. 1975; Hökfelt et al. 1975; Dubois 1975; Orci et al. 1975). With regard to the gut, Dubois (1975), Hökfelt and his coworkers (1975), and Polak and her coworkers (1975) described a positive reaction in a part of basal granulated cells of the gastric mucosa and intestinal crypt in several mammalian species including dogs. Furthermore, Polak and her coworkers (1975) claimed that the somatostatin-positive cells in the gut correspond to D-cells in the electron-microscopic classification of the gut endocrine cells (Solcia et al. 1973). However, the physiological meaning of somatostatincontaining cells in the gut has not yet been fully explained. The purpose of the present study is to investigate the morphological differences, if any, between

Received for publication, September 1, 1976.

Director: Prof. M. Matsuoka. 
somatostatin-positive cells in the gut and those in other tissues, and to obtain a clue to clarify the function of the gut somatostatin-containing cells.

\section{Materials and Methods}

\section{Anti-somatostatin antisera}

Synthetic somatostatin of cyclic form supplied by the Peptide Institute Research Foundation, Osaka, Japan, was coupled with bovine serum albumin (BSA) using the glutaraldehyde method (Ito and Kobayashi 1976). The somatostatin-BSA conjugate thus prepared was emulsified with complete Freund's adjuvant (Difco) and subcutaneously injected monthly into four adult male New Zealand white rabbits. The antisera used in the present study were prepared after two boosters by the routine method. Anti-rabbit IgG-FITC was purchased from the Seikagaku-Kogyo, Ltd., Tokyo, Japan.

\section{Immunofuorescence microscopy}

Pieces of the canine gut including the body and pyloric portion of the stomach, duodemun, jejunum, ileum and colon were excised and immersed in Bouin's fluid at room temperature for $90 \mathrm{~min}$. They were then dehydrated through a graded ethanol series and embedded in paraffin. Sections, $6 \mu \mathrm{m}$ thick, were placed on gelatin-coated glass slides.

Sections deparaffinized in xylene were treated with the anti-somatostatin antisera at $37^{\circ} \mathrm{C}$ for $90 \mathrm{~min}$, followed by antirabbit IgG-FITC at $37^{\circ} \mathrm{C}$ for $40 \mathrm{~min}$, and then examined with an Olympus BH-LSF fluorescent microscope.

\section{Control study}

The specificity of the reaction was investigated as follows: a) Sections were incubated with anti-somatostatin antisera saturated with an excess amount of the synthetic somatostatin, glucagon (Lilly Co., Ltd.) and synthetic gastrin (ICI), highly purified porcine secretin (supplied by Dr. S. Tachibana of the Eisai Pharmac. Co., Ltd.), before the treat. ment with anti-rabbit IgG-FITC. b) Sections were treated with normal rabbit serum and incubated with anti-rabbit IgG-FITC. and c) Sections were treated with either antisomatostatin antisera or anti-rabbit IgG-FITC alone, and then examined with the fluorescence microscope.

\section{Results}

\section{Localization of somatostatin-positive cells}

Cells reacting with anti-somatostatin antisera (somatostatin-positive cells) were demonstrated in the neck portions of the gastric gland of the pyloric portion of the stomach as shown in Fig. 1. They were also seen in the bottom of the intestinal crypt in the duodenum, jejenum and ileum. These cells were oval or triangular and reached the lumen with a narrow cytoplasmic process as seen in Figs. 2 and 3 (open type).

Weak but distinct fluorescence was seen in the apical portion of the chief cells in the bottom of the fundic gland. However, they were not immunohistologically characterized as cells reacting with anti-somatostatin antisera, as similar fluorescene was also found in the specimen treated with the anti-somatostatin antisera previously absorbed with an excess somatostatin.

In the colon, no epithelial cells were positively stained with the antisomatostatin antisera used in the present study. 


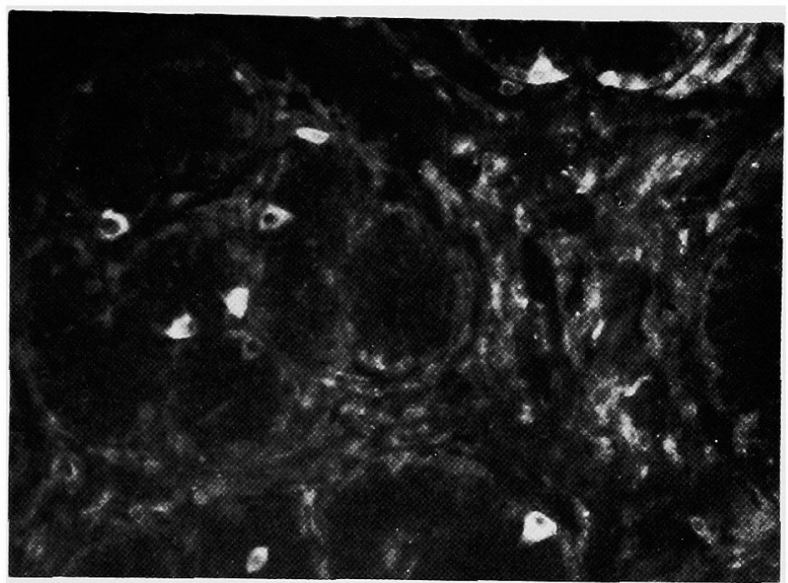

Fig. 1. An immunofluorescent micrograph showing cells reacting with anti-somatostatin antibody in the neck portion of pyloric glands. Immunofluorescence is localized in the cytoplasm but not in the nucleus. $\times 250$

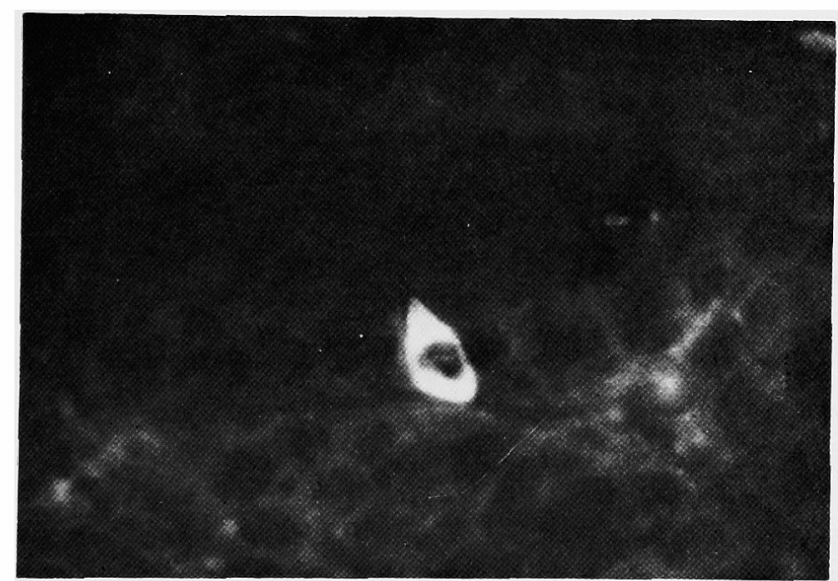

Fig. 2. An immunofluorescent micrograph showing the detail of the cell. This cell reaches the lumen by its apical process. $\times 700$

\section{Specificity of the immunofuorescence}

It was noted that the intensity of immunofluorescent reaction due to the nontreated anti-somatostatin antisera was not different from that due to the antisomatostatin antisera absorbed with one of the following three hormones; gastrin, glucagon and secretin. This finding excluded the possibility that these three hormones are cross-reactive to the present anti-somatostatin antisera. Furthermore, the formation of complex of somatostatin and anti-somatostatin antibody was confirmed, as positive cells were not found in other control sections. 


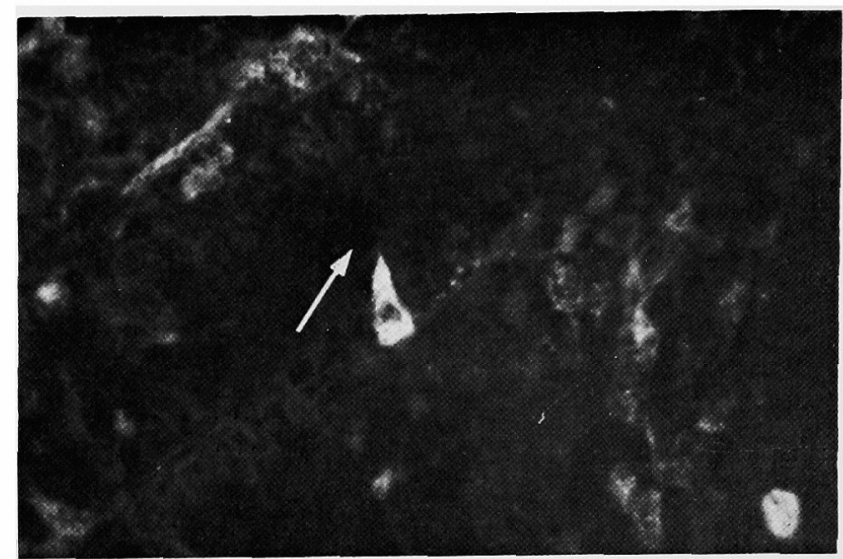

Fig. 3. An immunofluorescence micrograph showing a somatostatin-positive cell in the ileum. This cell reaches the cryptal lumen as indicated by the arrow. $\times 700$

\section{Discussion}

The present study shows that the somatostatin-positive cells in the gut have contact with the gut lumen through a tapered apical process (open-type cell). The finding suggests that somatostatin in the gut may be released in response to information of metabolic changes in the gut. From the view point of the function of gastrointestinal hormones, it has been described that gastrointestinal hormonecontaining open type cells release their hormones in response to stimuli in the gut lumen. There have been the following reports: the release of secretin in response to changed $\mathrm{pH}$ (Bayliss and Starling 1902), the release of secretory granules from G-cell in electron-microscopical classification, which seems to contain gastrin, by oral administration of $3 \% \mathrm{NaHCO}_{3}$ (Kobayashi and Fujita 1973) and the release of glucagon-like-immunoreactivity (GLI) by orally administrated glucose (Unger et al. 1968) and immunohistochemical demonstration of open type GLI-containing cells (Ito and Kobayashi 1976). Recently, Fujita and Kobayashi (1971) infused $0.1 \mathrm{~N}$ hydrochloric acid into the dog stomach and demonstrated electron-microscopically exocytotic release of secretory granules in the D-cell of the pyloric gland of the stomach. The hormone secreted from the D-cell in the stomach in response to the infusion of hydrochloric acid seems to be somatostatin, since Polak et al. (1975) have demonstrated by both immunohistochemical and conventional histological methods that $\mathrm{D}$-cells in the gut contain somatostatin. These previous observations support the present hypothesis that the secretion of somatostatin in the stomach is regulated by the extrinsic stimuli through the gut lumen. In contrast to the regulatory mechanism of the somatostatin secretion in the stomach, the somatostatin in other organs, such as the hypothalamus, posterior pituitary, thyroid gland and pancreas, seems to be released in response to the stimuli in the blood, since they are completely embedded in tissue space.

Barros D'Sa et al. (1975) and Gomez-Pan et al. (1975) reported that intravenous 
infusion of somatostatin suppressed the secretion of gastric acid in response to stimuli of acid production and this effect was mediated by a direct action of somatostatin on parietal cells, since this effect was also found during pentagastrin administration. Fujita and Kobayashi (1971) also demonstrated the release of secretory granules which were later referred to as somatostatin, when hydrochloric acid was orally administrated. It is, therefore, of interest to note the functional interrelationship between the somatostatin-positive cells in the pyloric gland of the stomach and hydrochloric acid secretion from the parietal cells. Recently, Tayer and Torrance (1975) examined the direction of blood flow within the rat stomach using the isotope ${ }^{86} \mathrm{RbCl}$ and demonstrated that an antral-body portal system exists in the rat stomach. They inferred that hormones in the pyloric gland are directly conveyed to the body of the stomach without going through the circulatory system. In view of the present finding that somatostatinpositive cells are distributed in the pyloric gland and are in contact with the gut lumen through a tapered apical process, it is not an exaggeration to suppose that there might be an inhibiting action of somatostatin on the secretion of hydrochloric acid from parietal cells through the antral-body portal system.

In the present study, somatostatin-positive cells were demonstrated not only in the stomach but also in the intestine. It may be reasonable to speculate that the intestinal somatostatin-positive cells as those in the stomach secrete somatostatin in response to some adequate stimuli in the lumen accompanying the digestion and absorption of nutrient materials. However, the exact function of somatostatin in the intestine remains to be studied.

\section{References}

1) Alberti, K.G., Christensen, N.J., Christensen, S.E., Hansen, A.P., Iversin, J., Lundbaek, K., Seyer-Hansen, K. \& Orskov, H. (1973) Inhbition of insulin secretion by somatostatin. Lancet, 2, 1299-1301.

2) Barros D'Sa, A.A.J., Bloom, S.R. \& Baron, J.H. (1975) Direct inhibition of gastric acid by growth-hormone release-inhibiting hormone in dogs. Lancet, 1, 886-887.

3) Bayliss, W.M. \& Starling, E.H. (1902) The mechanism of pancreatic secretion. $J$. Physiol. (Lond.), 28, 325.

4) Bloom, S.R., Mortimer, C.H., Thorner, M.O., Besser, G.M., Hall, R., Gomez-Pan, A., Roy, V.M., Russell, R.C.G., Coy, D.H., Kastin, A.J. \& Schally, A.V. (1974) Inhibition of gastrin and gastric-acid secretion by growth-hormone release-inhibiting hormone. Lancet, 2, 1106-1109.

5) Brazeau, P., Vale, W., Burgus, R., Ling, N., Butcher, M., Rivier, J. \& Guillemin, R. (1973) A hypothalamic polypeptide that inhibits the secretion of pituitary growth hormone. Science, 179, 71-79.

6) Dubois, M.P. (1975) Immunoreactive somatostatin is present in discrete cells of the endocrine pancreas. Proc. nat. Acad. Sci. USA, 72, 1340-1343.

7) Fujita, J. \& Kobayashi, S. (1971) Experimentally indueed granule release in the endocrine cells of dog pyloric antrum. $Z$. Zellforsch., 116, 52-60.

8) Gerich, J.E., Lorenzi, M., Schneider, V., Karam, J.H., Rivier, J., Guillemin, R. \& Forsham, P. (1974) Effects of somatostatin on plasma glucose and glucagon levels in human diabetes mellitus: Pathophysiologic and therapeutic implications. New. Engl. J. Med., 291, 544-547. 
9) Gomez-Pan, A., Reed., J.D., Albinus, M., Shaw, B., Hall, R., Besser, G.M., Coy, D.H., Kastin, A.J. \& Schally, A.V. (1975) Direct inhibition of gastric and pepsin secretion by growth-hormone release-inhibiting hormone in cats. Lancet, 1, 888-890.

10) Hökfelt, T., Efeudic, S., Hellerstrom, C., Johansson, O., Luft, R. \& Arimura, A. (1975) Cellular localization of somatostatin in endocrine-like cells and neurons of the rat with special references to the A-cells of the pancreatic islets and to the hypothalamus. Acta endocr. (Kbh.), 80, Suppl. 200, 1-40.

11) Ito, S. \& Kobayashi, S. (1976) Immunohistochemical demonstration of glucagon- and GLI-containing cells in the canine gut and pancreas. Arch. histol. jap., 39, 193-202.

12) Kobayashi, S. \& Fujita, T. (1973) Emiocytotic granule release in the basal-granulated cells of the dog induced by intra-luminal application of adequate stimuli. In: Gastroentero-pancreatic Endocrine System, edited by T. Fujita, Igaku Shoin, Tokyo, pp. 49-58.

13) Luft, R., Efendic, S., Hokfelt, T., Johansson, O. \& Arimura, A. (1974) Immunohistochemical evidence for the localization of somatostatin-like immunoreactivity in a cell population of the pancreatic islets. Med. Biol., 52, 428-430.

14) Orci, L., Baetens, D., Dubois, M.P. \& Rufener, C. (1975) Evidence for the C-cell of the pancreas secreting somatostatin. Horm. Metab. Res., 7, 400-402.

15) Polak, J.M., Pearse, A.G.E., Grimelius, L., Bloom, S.R. \& Arimura, A. (1975) "Growth-hormone release-inhibiting hormone in gastrointestinal and pancreatic D. cells. Lancet, 1, 1220-1222.

16) Solcia, E., Pearse, A.G.E., Grube, D., Kobayashi, S., Bussolati, G., Creutzfelt, W. \& Gepts. (1973) Revised Wiesbaden elassification of gut endocrine cells. Rendiconti Romani di Gastroenterol., 5, 13-16.

17) Tayler, T.V. \& Torrance, B. (1975) Is there an antralbody portal system in the stomach ? Gut, 16, 781-784.

18) Unger, R.H., Ohneda, A., Valverde, I., Eisentraut, A.M. \& Exton, J. (1968) Characterization of the responses of circulating glucagon-like immunoreactivity of intraduodenal and intravenous administration of glucose. J. clin. Invest., 47, 48-65. 